\title{
Partially absorbed cataractous lens in the anterior chamber revealing neglected severe ocular contusion: a case report
}

\author{
Viola Andin Dohvoma ${ }^{\text {* }}$, Steve Robert Ebana Mvogo', Pepin Williams Atipo-tsiba², Emilienne Epee', \\ Paul Jean Adrien Atangana ${ }^{3}$, Samuel Amvene $\mathrm{Nko}^{\prime} \mathrm{O}^{1}$ and Côme Ebana Mvogo ${ }^{1}$
}

\begin{abstract}
Background: Ocular contusion can produce severe lesions, which if not treated appropriately and promptly, can lead to visual impairment. Ocular contusion in childhood may not be reported by children.

Case presentation: A 27 year old female presented with a partially absorbed cataractous lens that was dislocated into the anterior chamber of her left eye. There was mild anterior chamber reaction. She reported no history of ocular trauma; but associated findings and further investigations were in favour of a post-traumatic aetiology.
\end{abstract}

Conclusion: All ocular injuries require a detailed ophthalmological examination to assess vision and the extent of lesions.

Keywords: Cataract, Retinal detachment, Ocular contusion, Case report

\section{Background}

Ocular trauma is a major cause of ocular morbidity. Worldwide, approximately 1.6 million people are bilaterally blind, 2.3 million are bilaterally visually impaired and almost 19 million have unilateral blindness or visual impairment due to trauma [1]. Eye injuries are a leading cause of non-congenital unilateral blindness in children [2].

Aetiologically, such injuries are mostly accidental in children, unlike intentional violent assault in adults. Such accidental injuries, if not reported by the child, can go unnoticed by the parents, making it difficult to obtain the critical history associated with it.

\section{Case presentation}

A 27 year old lady was seen for mild pain in her left eye which has been blind since late childhood. She noticed a whitish lesion in the left eye 2 weeks prior to hospital visit. Over the past year, she had noticed a few intermittent episodes of redness in the eye. No recent or past

\footnotetext{
* Correspondence: andinv@gmail.com

${ }^{1}$ Faculty of Medicine and Biomedical Sciences, University of Yaoundé I, PO

Box 3851, Messa, Yaoundé, Cameroon

Full list of author information is available at the end of the article
}

history of ocular trauma was reported. This was her first ever eye consultation.

Vision was normal in the right eye and no perception of light in the left eye. Anterior segment examination was normal in the right eye. There was a partially absorbed lens in the anterior chamber of the left eye (Fig. 1) and a mild anterior chamber reaction with $1+$ cells. Intraocular pressures were $12 \mathrm{mmHg}$ and $10 \mathrm{mmHg}$ for the right and left eyes respectively. Extraocular movements were full in both eyes. Pupillary light reflex was normal in the right eye and absent in the left eye.

A yellowish glow was observed from the retina of the left eye (Fig. 1). An old complete retinal detachment and a large retinal tear at the equator between the 2 O'clock and 3 O'clock meridians were observed on three-mirror contact lens examination. Retinal examination was normal for the right eye. On grey-scale ultrasound, the detached retina was seen as an echogenic $\mathrm{V}$-shaped membrane extending from the optic disc into the anterior part of the vitreous (Fig. 2). Fine hyper-echogenic particles were present in the vitreous, indicative of vitreous haemorrhage. Histology of the extracted material from the anterior chamber revealed an amorphous fibrous calcified tissue (Fig. 3). 


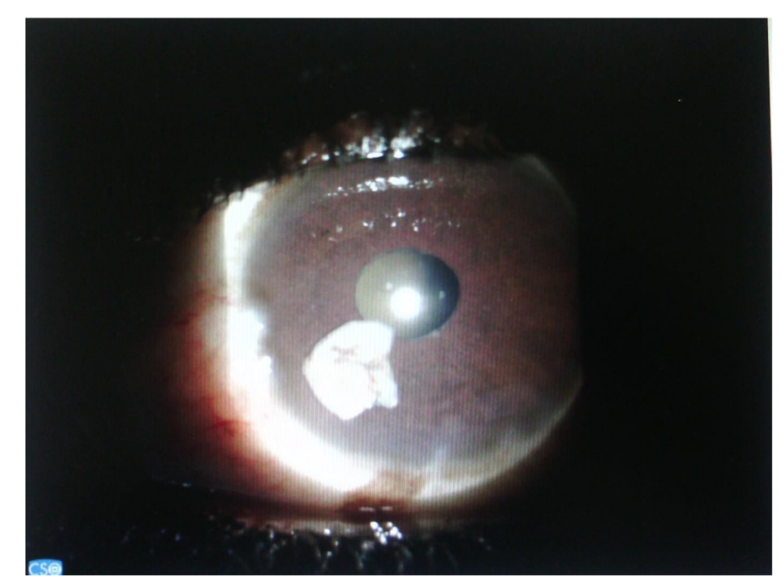

Fig. 1 slit lamp photograph - partially absorbed cataract dislocated into the anterior chamber

We arrived at a diagnosis of neglected ocular contusion, which could explain all the findings in this patient. The lens material in the anterior chamber was extracted through a $3.2 \mathrm{~mm}$ corneo-scleral tunnel incision. Topical antibiotics and steroids were used in the post-operative period. The pain resolved completely thereafter and the eye has remained quiet at her last follow-up visit 1 year after surgery (Table 1 ).

\section{Discussion and conclusions}

Ocular contusion can cause damages in both the anterior and posterior segments. The anterior segment is affected by the coup and compression mechanisms. The contre-coup mechanism accounts for posterior segment injuries as the shock waves that cross the eye strike the posterior pole.

Cataract in ocular contusion results either from a dysfunction of the lens epithelium, leading to oedema of superficial cortical lens fibres that subsequently undergo

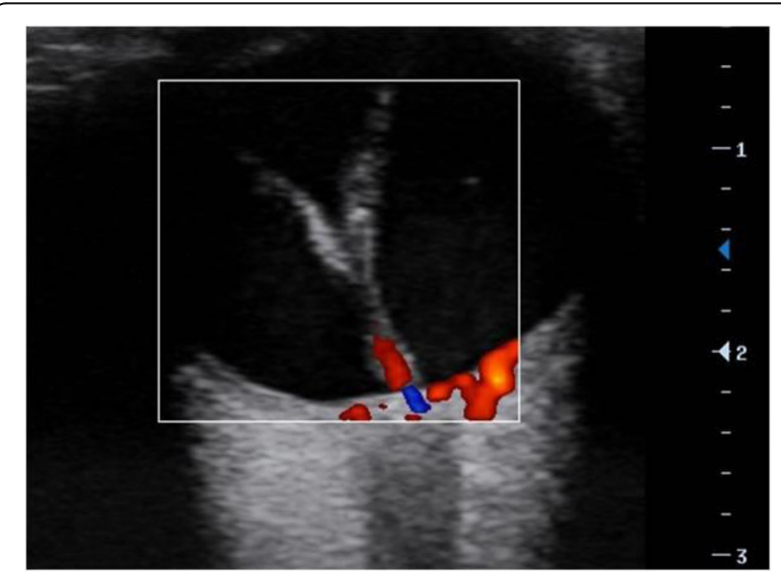

Fig. 2 ocular ultrasound - a V-shaped membrane attached to the optic nerve head, indicative of a total retinal detachment

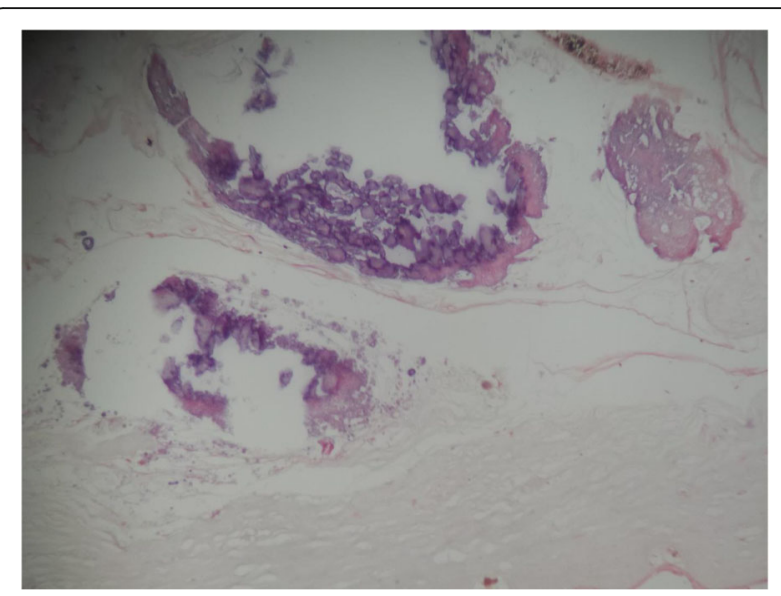

Fig. 3 histology of lens material (stained with haematoxylin and eosin seen at $\times 40$ magnification) - fibrous calcified tissue

degeneration [3] or from a rupture of the anterior lens capsule. Bannit et al. in 2009 reported 3 cases of blunt trauma causing rupture of the anterior lens capsule with cataract formation [4]. They proposed that the anterior lens capsule may have been torn by direct contusion from rapid focal indentation of the cornea onto the lens (coup injury) or by a fluid-mechanical, anteriorly directed rebound of the vitreous, bursting open the anterior capsule (contre-coup injury). Posterior capsule rupture may also occur secondary to blunt trauma and lead to progressive cataract formation $[5,6]$. Partially exposed lens cortex can cause little or no anterior chamber reaction. In our patient, there was mild anterior chamber reaction, indicative of the presence of some cortical material. Elsewhere, spontaneous cataract absorption has been reported with no secondary uveitis nor glaucoma $[7,8]$.

Equatorial stretching from ocular compression can disrupt the lens capsule, the ciliary zonule, or both. Partial or total zonular damage may occur in blunt injuries, resulting in partial or total dislocation of the lens [9]. Zonular damage probably occurred in our patient, leading to secondary dislocation. Primary post traumatic lens dislocation into the anterior chamber is usually associated with pain due to angle-closure glaucoma.

Posterior segment injuries which result from the contre-coup mechanism may include commotio retinae,

Table 1 Timeline

1 Intermittent redness in left eye over the past year

2 Whitish lesion in her left eye

3 Mild pain in her left eye

4 Examination reveals dislocated lens material in the anterior chamber with anterior chamber reaction; retinal hole and old retinal detachment.

5 Surgical extraction of lens material

6 Resolution of pain 
macular oedema and holes, retinal tears and vitreous haemorrhages. Traumatic breaks or retinal detachment may not occur immediately after injury. Goffstein and Burton observed that $60 \%$ were diagnosed within 8 months of injury [10]. Immediate retinal detachment results from impact necrosis, while late detachment results from leakage of fluid from the choroid into the sub-retinal space and movement of vitreous fluid through retinal breaks [11].

Ocular contusion may not be reported by children or adolescents, yet be responsible for severe lesions which could be sight-threatening. Parents, guardians and child care givers should pay attention to any observed changes in the eye or visual behaviour and seek immediate ophthalmic care.

\section{Acknowledgements}

None.

\section{Funding}

No funding was obtained.

\section{Availability of data and materials}

All data supporting our findings are contained within the manuscript.

\section{Authors' contributions}

DVA was responsible for obtaining consent, acquiring the data and drafting the manuscript. EMSR, EE and EMC participated in patient care and helped establish the final clinical diagnosis. APW and EE critically revised the manuscript. AJPA performed the histology examination of the extracted lens material and critically revised the manuscript. NAS performed the ultrasound examination and critically revised the manuscript. EMC assisted in drafting its final version. All authors read and approved the final version of the manuscript.

\section{Ethics approval and consent to participate}

The Ethics Committee of the Faculty of Medicine and Biomedical Sciences waived the need for formal approval in this case. Full consent for procedures described was obtained from the patient.

\section{Consent for publication}

Full verbal and written consent has been obtained from the patient for submission of this manuscript for publication.

\section{Competing interests}

The authors declare that they have no competing interests.

\section{Publisher's Note}

Springer Nature remains neutral with regard to jurisdictional claims in published maps and institutional affiliations.

\section{Author details}

${ }^{1}$ Faculty of Medicine and Biomedical Sciences, University of Yaoundé I, PO Box 3851, Messa, Yaoundé, Cameroon. ${ }^{2}$ Marien Ngouabi University of Brazzaville, Brazzaville, Congo. ${ }^{3}$ Faculty of Medicine and Pharmaceutical Sciences, University of Douala, Douala, Cameroon.

Received: 8 December 2016 Accepted: 30 October 2017

Published online: 06 November 2017

\section{References}

1. Négrel AD, Thylefors B. The global impact of eye injuries. Ophthalmic Epidemiol. 1998;5(3):143-69.

2. National Society for the Prevention of Blindness. Fact sheet. Vision problems in the US. New York: National Society for the Prevention of Blindness; 1980.

3. Asano N, Schlötzer-Schrehardt U, Dörfler S, Naumann GO. Ultrastructure of contusion cataract Arch Ophthalmol Chic III 1960. 1995;113(2):210-5.
4. Banitt MR, Malta JB, Mian SI, Soong HK. Rupture of anterior lens capsule from blunt ocular injury. J Cataract Refract Surg. 2009;35(5):943-5.

5. Rao SK, Parikh S, Padhmanabhan P. Isolated posterior capsule rupture in blunt trauma: pathogenesis and management. Ophthalmic Surg Lasers. 1998;29(4):338-42.

6. Yasukawa T, Kita M, Honda Y. Traumatic cataract with a ruptured posterior capsule from a nonpenetrating ocular injury. J Cataract Refract Surg. 1998; 24(6):868-9.

7. Ahmad. A case of bilateral, spontaneous absorption of lenses. Digit J Ophthalmol [Internet]. 2011 [cited 2016 Oct 28]; Available from: http:// www.djo.harvard.edu/site.php?url=/physicians/cr/1471.

8. Mohan M, Bartholomew RS. Spontaneous absorption of a cataractous lens. Acta Ophthalmol Scand. 1999;77(4):476-7.

9. Ajamian PC. Traumatic cataract. Optom Clin. 1993;3(2):49-56.

10. Goffstein $R$, Burton TC. Differentiating traumatic from nontraumatic retinal detachment. Ophthalmology. 1982;89(4):361-8.

11. Johnston PB. Traumatic retinal detachment. Br J Ophthalmol. 1991;75(1): 18-21.
Submit your next manuscript to BioMed Central and we will help you at every step:

- We accept pre-submission inquiries

- Our selector tool helps you to find the most relevant journal

- We provide round the clock customer support

- Convenient online submission

- Thorough peer review

- Inclusion in PubMed and all major indexing services

- Maximum visibility for your research

Submit your manuscript at www.biomedcentral.com/submit
) Biomed Central 